EGU Stephan Mueller Special Publication Series, 2, 161-170, 2002

(C) European Geosciences Union 2002

\title{
On deep circulation of meteoric waters within Baikal Rift
}

\author{
L. Z. Granina ${ }^{1}$, E. Callender ${ }^{2}$, V. D. Mats ${ }^{1}$, and L. P. Golobokova ${ }^{1}$ \\ ${ }^{1}$ Limnological Institute of Siberian Division of Russian Academy of Sciences, Irkutsk, Russia \\ ${ }^{2}$ US Geological Survey, Reston, VA, USA
}

Received: 16 October 2000 - Revised: 19 December 2001 - Accepted: 29 January 2002

\begin{abstract}
Anomalies in pore water (PW) composition have been found in the $100 \mathrm{~m}$-long core BDP-93 that was drilled in Southern Lake Baikal, in four piston cores taken from the same region, and in recent sediments from Frolikha Bay, a hydrothermal vent site in Northern Lake Baikal. PW anomalies are manifested as significant increases in concentrations of sulphates, bicarbonates, chlorides, and the ions of alkali and alkali-earth metals, in some cases, in the appearance of specific minor elements. These increases are recorded at single depths within a core. Anomalies were found at different depths below the sediment-water interface (from centimetres to tens of meters) and the level of pore water enrichment by these components varies from station to station.
\end{abstract}

Anomalies have specific features in each of the lake basins. It is shown that there is a genetic relationship between sub-aquatic and terrestrial centres of thermal-water discharge in Northern Lake Baikal. PW data obtained in Frolikha Bay exemplify a sub-aquatic hydrothermal water discharge occurring in the lake. These anomalous PW concentrations presumably are due to the leaching of ambient sediments. In addition, some fraction of the sulphates, halogens, and minor elements may have multiple geneses, including the input of fluids from deep zones of the earth's crust and mantle that occur through the fault system in areas of tectonic breakdowns.

In Southern Lake Baikal, in the Selenga River delta, ground waters of specific composition that are relics of ancient salt lakes could serve as a source of anomalous concentrations in PW components. Their influence may be realized through the extensive zones of increased permeability. Effect of "vagabonding sieves" could contribute to the penetration of water fluids through friable deposits, including clay-rich sediments. This effect may be of great importance in the seismically active Baikal rift zone.

Key words. Sediments, pore water, anomalies, concentration, Baikal rift, fault, discharge

Correspondence to: L. Z. Granina (liba@ lin.irk.ru)

\section{Introduction}

Pore water (PW) is quite different from that of the initial waters entrapped by the sediments. Due to numerous processes that constitute early diagenesis (decomposition of organic mater, cation exchange, formation of new mineral phases, sulphate reduction, dissolution of carbonates - diatom frustules - mineral particles, etc.), the initial calcium bicarbonate Baikal water is transformed into bicarbonate-sulphate, chloride and mixed types of pore waters (Mizandrontsev, 1975). The content of total dissolved solids (TDS) in PW increases and the proportion between ions changes with depth. However, parallel with these regular changes in PW chemistry, anomalously high concentrations of chlorides, 2 to 3 orders of magnitude greater than those in Baikal water, have been found in some pore waters (Mizandrontsev, 1975). Anomalies were registered at the stations located near tectonic faults stretched along the western shore of Northern Lake Baikal. Such occurrences allow the author to suppose that chlorides enter the bottom sediments through the fault system in the zones of tectonic breakdowns.

Results of recent studies show that not only in this part of Northern Lake Baikal, but also in some other regions of the lake, there are pore waters with chlorides and Na-ions whose concentrations are tens- and hundreds-times greater than their concentration in Lake Baikal water. Often the concentrations of sulphates, bicarbonates, and $\mathrm{K}, \mathrm{Mg}, \mathrm{Ca}$ ions are also increased in the same samples and, in some cases there are bromides in these pore waters. In the same way as it was described in (Mizandrontsev, 1975), the peaks of concentration occur at different depths within the sediment, including sedimentary layers close to the sediment-water interface.

It is of great interest that ambient sediments do not contain large amounts of the components listed above. Thus, pore water enrichment in such constituents can not only be due to direct water-sediment interaction. In this paper, based on the existent data, we try to explain the origin of the anomalies in pore water composition. 


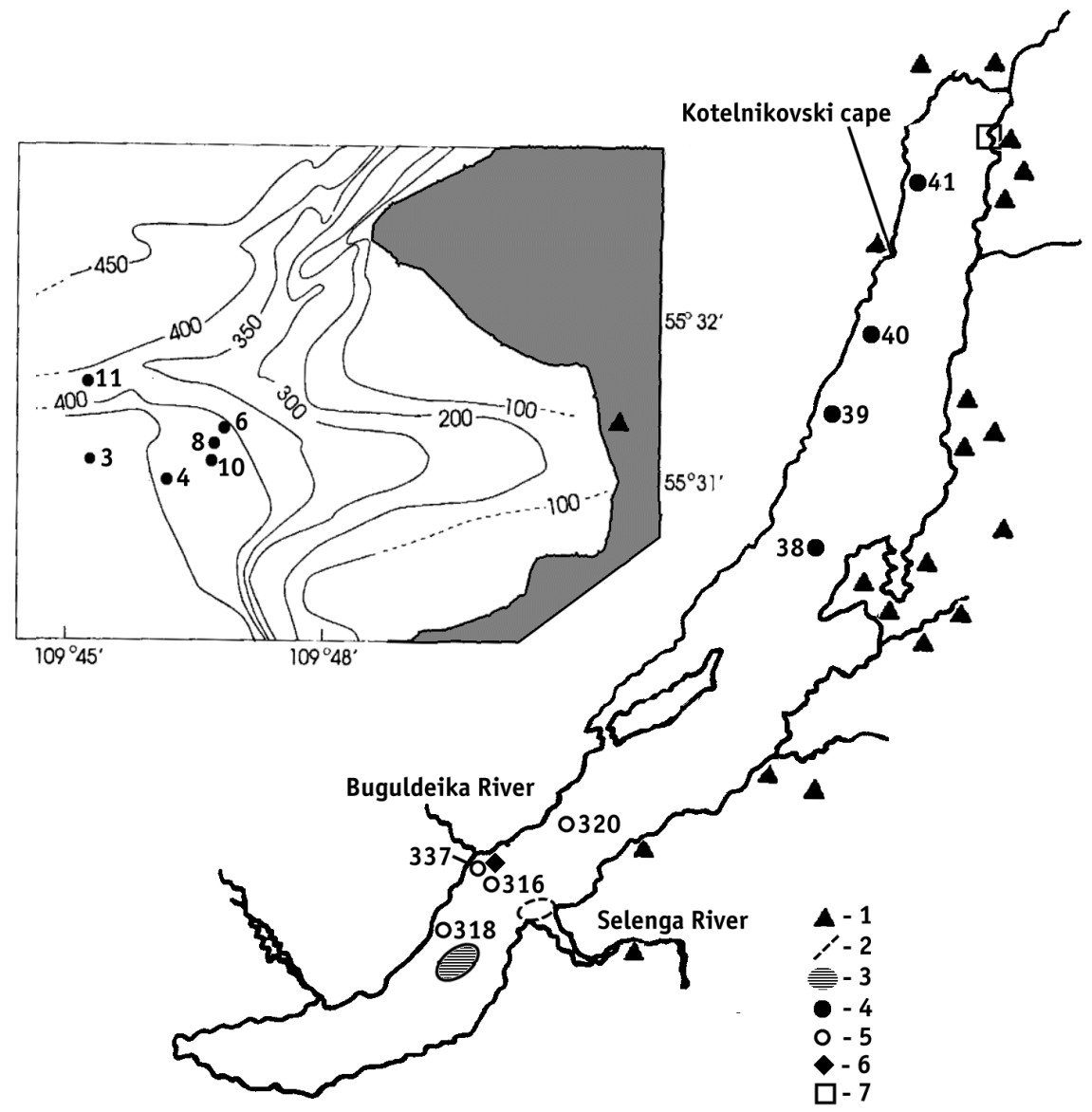

Fig. 1.

1 - Location of thermal springs in nearshore zone of Lake Baikal

2 - petroleum-searching holes in the Selenga River delta (Lomonosov, 1974) 3 - region, where gas hydrates are found in the surface sedimentary layer (Klerkx et al., 2000) and stations characterized by pore water anomalies: 4 - from (Mizandrontsev, 1975); 5 - stations with anomalous pore water composition in Southern Baikal; 6 - drilling hole BDP-93; 7 - region of hydrothermal sub-aquatic discharge in Frolikha Bay; a scheme of the bay and station numbers are shown on the inset.

\section{Materials and methods}

Sediments characterized by anomalies in PW chemistry and, in some cases, isotopic composition, are found in the southern ( 1 group) and the northern ( 2 group) basins of the lake (Fig. 1):

1 group

(a) four cores, from 1 to $8 \mathrm{~m}$ in length, sampled by piston coring device in the region near the mouth of the Buguldeika River (st. 316, 337), and to the south (st. 318) and to the north (st. 320) of this area;

(b) a $100 \mathrm{~m}$ long core, drilled in the same region (BDP-93). 2 group

Four short cores, up to $20 \mathrm{~cm}$ in length, taken from the region of hydrothermal discharge (vent area) in Frolikha Bay located in Northern Lake Baikal (st. 4, 6, 8, 10), and short cores from control stations (st. 3,11$)$ that are located near the vent area.

Pore waters were squeezed from the short cores immediately after sampling on board ship using a whole core squeezer (Jahnke, 1988). A hydraulic sediment squeezer system was used to obtain PW from long cores (under the pressure of up to $150 \mathrm{~atm}$ ). The same method was used in the laboratory to get PW from the 100-m drill core. During squeezing, PW was passed through filters of $0.22 \mu \mathrm{m}$ pore size. Anion concentrations were measured by HPLC and the relative error of analyses was around 7\%. Concentration of cations was analysed by direct current plasma/atomic emission spectrometry with the error of measurements between 2 and $3 \%$. PW isotopic composition was studied in the US Geological Survey by the method described in (Seal and Shanks, 1998).

\section{Results}

So-called "background" concentrations of PW major ions, which are average concentrations in the surface sedimentary layer, are presented in Table 1. While drilling, the upper sedimentary sequence was lost; therefore the first horizon studied in BDP-93 core is $142 \mathrm{~cm}$ below the sediment-water interface. Coefficients of PW enrichment in major ions (K) are calculated as follows: $\boldsymbol{K}=\boldsymbol{C}_{\max } / \boldsymbol{C}_{\text {surf }}$, where $C_{\max }$ is maximal concentration in the core, $C_{\text {surf }}$ is the concentration in the upper sedimentary layer studied (Table 2). PW anomalies are different in each group of sediments, thus they are discussed separately.

1 group (a)

The highest PW anomalies are found in the cores taken at stations 316 and 337 located near the drilling site (Fig. 1). There are high concentrations of many PW components at the horizons 169 and $243 \mathrm{~cm}$ at st. 316 (Fig. 2): the concentration 
Table 1. Concentration of major ions in Baikal water and pore water $(\mathrm{mg} / \mathrm{L})$

\begin{tabular}{|c|c|c|c|c|}
\hline \multirow[b]{2}{*}{ Ion } & \multirow[b]{2}{*}{$\begin{array}{l}\text { Average concentration } \\
\text { in Baikal water } \\
\text { (Falkner et al., 1991) }\end{array}$} & \multicolumn{3}{|c|}{$\begin{array}{c}\text { Background* (first number) and maximal } \\
\text { (number in brackets) concentration in Baikal pore water }\end{array}$} \\
\hline & & $\begin{array}{c}\text { Southern Baikal } \\
\text { (st. } 316,318 \\
320,337)\end{array}$ & $\begin{array}{l}\text { Southern } \\
\text { Baikal }^{2} \\
\text { BDP-93 }\end{array}$ & $\begin{array}{c}\text { Northern Baikal }{ }^{3} \\
\text { Frolikha Bay } \\
\text { (st. } 4,6,8,10)\end{array}$ \\
\hline $\mathrm{HCO}_{3}^{-}$ & 66.7 & 76 (393) & $66.3(674)$ & $67.6(810)$ \\
\hline $\mathrm{SO}_{4}^{2-}$ & 5.5 & $5.5(29)$ & $6.5(70)$ & $3.5(290)$ \\
\hline $\mathrm{Cl}^{-}$ & 0.4 & $0.8(130)$ & $2.6(45)$ & $1.3(31)$ \\
\hline $\mathrm{Na}^{+}$ & 3.6 & $3.9(89)$ & $5.2(111)$ & $5.7(253)$ \\
\hline $\mathrm{Ca}^{2+}$ & 16.1 & $16(79)$ & $15(104)$ & $15(91)$ \\
\hline $\mathrm{Mg}^{2+}$ & 3.0 & $3(21)$ & $2.9(23.5)$ & $2.3(20)$ \\
\hline $\mathrm{K}^{+}$ & 0.9 & $1.3(9)$ & $2.4(12)$ & $1.3(9)$ \\
\hline
\end{tabular}

* 1 - average concentration in surface sediments for 4 cores;

2 - concentration at the depth $142 \mathrm{~cm}$; explanation in the text;

3 - average concentration in surface sediments for 2 control stations (st. 3, 11)

Table 2. Coefficients (K) of Baikal pore water enrichment in major ions

\begin{tabular}{l|cccccccc}
\hline Station & $\begin{array}{c}\text { Horizon*, } \\
\mathrm{cm}\end{array}$ & $\mathrm{K}_{\mathrm{Cl}^{-}}$ & $\mathrm{K}_{\mathrm{Na}^{+}}$ & $\mathrm{K}_{\mathrm{K}^{+}}$ & $\mathrm{K}_{\mathrm{Mg}^{2+}}$ & $\mathrm{K}_{\mathrm{Ca}^{2+}}$ & $\mathrm{K}_{\mathrm{HCO}_{3}^{-}}$ & $\mathrm{K}_{\mathrm{SO}_{4}^{2-}}$ \\
\hline 6 & 18.5 & 2 & 14 & 6 & 4 & 2 & 9 & - \\
4 & 18 & 7 & 7 & - & 2 & 2 & 3 & - \\
8 & 12.5 & - & 3 & - & - & - & 2 & - \\
316 & 169 & 160 & 24 & 9 & 5 & 3 & 2 & 5 \\
337 & 339 & 100 & 19 & 8 & 5 & 2 & 4 & 4 \\
318 & 269 & 65 & 11 & 4 & 7 & 5 & 5 & 3 \\
320 & 42 & 4 & 6 & 3 & 2 & - & - & 2 \\
BDP-93 & 3724 & 17 & $\mathrm{n} / \mathrm{a}$ & $\mathrm{n} / \mathrm{a}$ & $\mathrm{n} / \mathrm{a}$ & $\mathrm{n} / \mathrm{a}$ & 2 & - \\
& 2538 & - & 6 & 3 & 3 & 3 & 5 & - \\
& 5539 & - & 12 & 4 & 4 & 4 & 6 & 11 \\
\hline
\end{tabular}

* $\quad$ - horizon (depth within a core), at which anomalously high concentration is recorded; n/a - no data; dash means $\mathrm{K}<2$.

Table 3. Significant $(>0.65)$ coefficients of ions coupled correlation in pore waters of anomalous compositions

\begin{tabular}{l|cccccccc}
\hline Station & $\mathrm{Na}-\mathrm{Cl}$ & $\mathrm{Mg}_{-} \mathrm{SO}_{4}$ & $\mathrm{Mg}-\mathrm{Cl}$ & $\mathrm{Ca}-\mathrm{SO}_{4}$ & $\mathrm{~K}-\mathrm{SO}_{4}$ & $\mathrm{~K}-\mathrm{Cl}$ & $\mathrm{Na}^{-} \mathrm{SO}_{4}$ & $\mathrm{Na}_{-} \mathrm{HCO}_{3}$ \\
\hline 316 & 1 & 0.90 & 0.95 & 0.74 & - & - & 0.80 & - \\
318 & 0.98 & 0.83 & 0.92 & 0.79 & - & - & - & - \\
320 & 0.91 & - & - & - & - & - & - & - \\
337 & 0.95 & 0.65 & 0.80 & - & - & 0.70 & - & - \\
BDP-93 & 0.71 & - & - & - & - & - & - & - \\
$4,6,8$ & 0.87 & - & - & - & - & - & - & 1 \\
10 & 0.96 & 1 & - & 1 & 1 & - & - & 0.65 \\
\hline
\end{tabular}

of chloride and Na-ions is one and two orders of magnitude greater than their concentration in Baikal water (Table 1); high concentrations of $\mathrm{PW}$ sulphate, $\mathrm{K}, \mathrm{Mg}$ and $\mathrm{Ca}$ ions are recorded at the same sample depths. At st. 316, PW is enriched in all components and the coefficient of enrichment ranges from 3 to 160 (Table 2). PW enrichment decreases towards the north (st. 318) and the south (st. 320), when mov- ing from the drilling site being the smallest at st. 320 (Table 2).

PW chloride and $\mathrm{Na}$ ion strongly correlate with each other (Table 3). There is also some correlation between major cations and sulphate at stations 316 and 318. In general, enrichment in sulphate is not high (2-5 times, Table 2). However, the occurrence of sulphate enrichment is, in itself, 

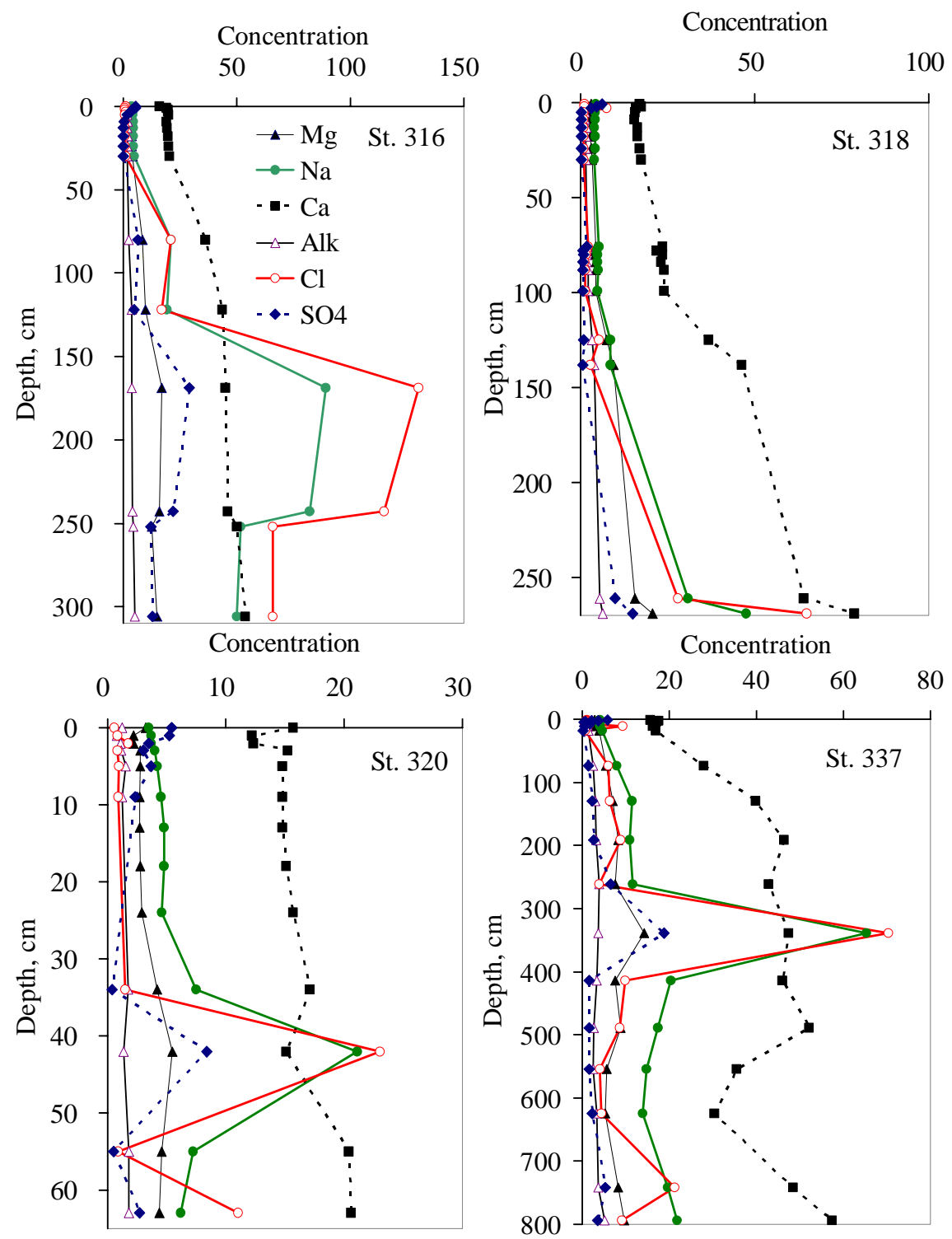

Fig. 2. Profiles of major pore water ions in the sediments of Southern Baikal (st. 316, 318, 320, 337). Concentration in $\mathrm{mg} / \mathrm{L}$, alkalinity in $\mu \mathrm{M}$.

of great importance, since the process of sulphate reduction results, as a rule, in the depletion of PW sulphate, sometimes leading to their complete disappearance (Mizandrontsev, 1975; Callender and Granina, 1992; Granina et al., 1994). Thus, anomalies in PW composition appear differently in different cores, as well as at different depths within the sediment (from $42 \mathrm{~cm}$ to $339 \mathrm{~cm}$, Table 2), showing no any regularity in occurrence.

\section{1 group (b)}

In the BDP-93 core there is a tendency for the concentration of PW major ions to increase gradually down the core (Fig. 3a, c). Not only does the sum of ions increase (Table 4), but also the cation ratio changes with depth in the core: $\mathrm{Na} / \mathrm{K}$ increases from approximately 2 to $9 ; \mathrm{Ca} / \mathrm{Mg}$ ratio decreases from 6 to 4. Calcium bicarbonate pore water in the upper part of BDP-93 core is replaced by a sodium-calcium bicarbonate type in the lower part of the core (Table 4). Such an increase in TDS and change in the type of PW is caused by the processes of leaching and cation exchange that was described earlier for Lake Baikal cores up to $3 \mathrm{~m}$ in length (Mizandrontsev, 1975). Besides such gradual pore-water metamorphosis with depth, a sharp increase in PW concentrations at some isolated horizons is also observed in the BDP-93 core (Fig. 3).

For example, Ca increases at 10 and $25 \mathrm{~m}$ depths (Fig. 3c), chloride at $31-37 \mathrm{~m}$, and sulphate at 50-55 m (Fig. 3a). The peaks of these concentrations do not correspond to each other along the core. Bromide appears at a depth of $19 \mathrm{~m}$; the concentration is changing from 0.9 to $4.5 \mathrm{mg} / \mathrm{L}$, a pattern of increasing with depth similar to chloride. The peaks of bromide and chloride do not always coincide. The $\mathrm{Br} / \mathrm{Cl}$ ratio ranges from 0.04 to 0.16 and has a tendency to increase with depth. However, the highest values range between $45 \mathrm{~m}$ and 

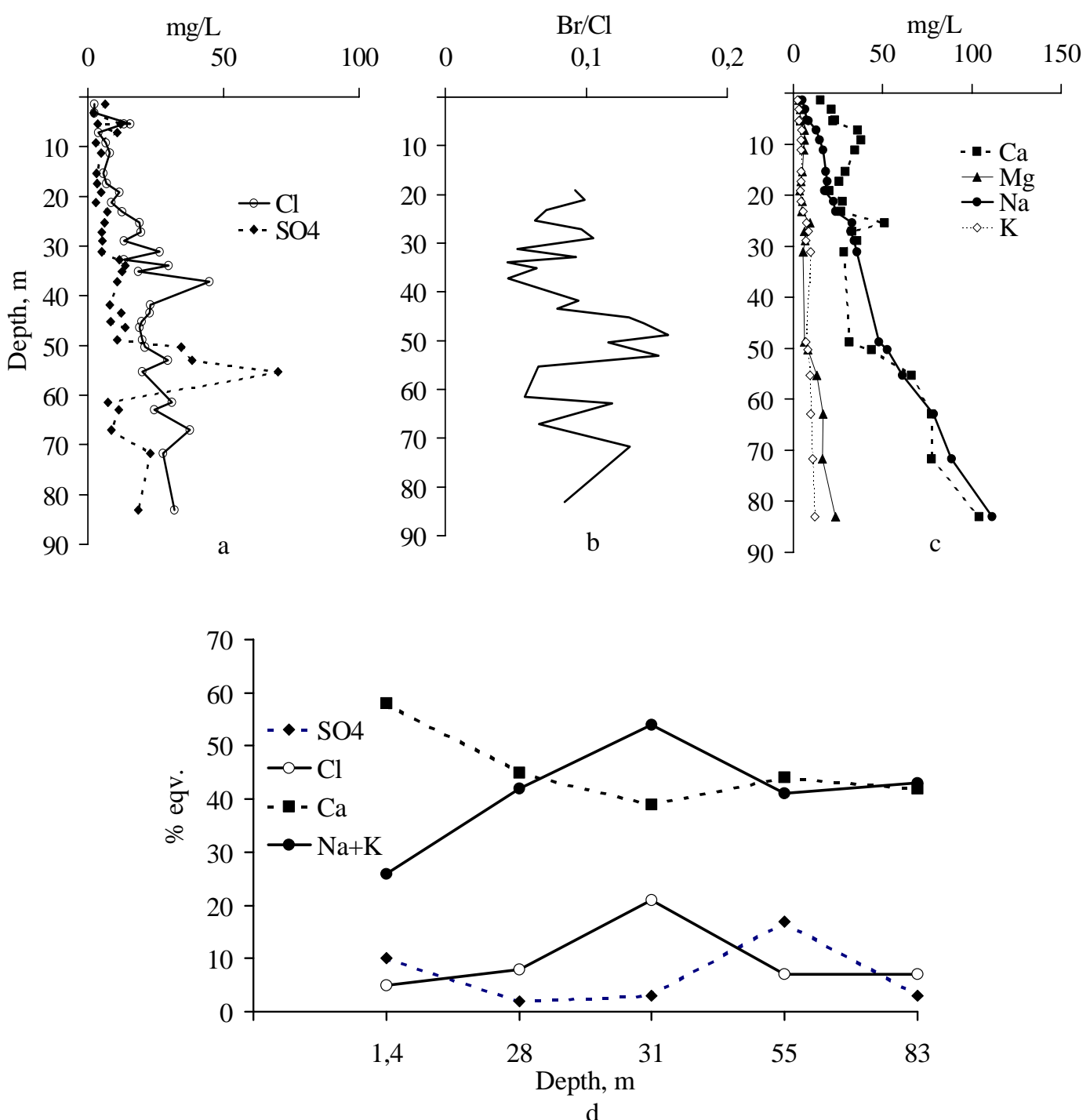

Fig. 3. Pore water chemistry in BDP-93 core: (a) concentration of $\mathrm{PW}$ sulphates and chlorides, $\mathrm{mg} / \mathrm{L}$; (b) vertical variability of $\mathrm{Br} / \mathrm{Cl}$ ratio; (c) concentration of PW cations, $\mathrm{mg} / \mathrm{L} ;$ (d) relationship between major PW ions, \% eqv.; depths within BDP-93 core are shown along horizontal axis, scale is conventional.

$55 \mathrm{~m}$ depth (Fig. 3b) and that depth interval is near the depth interval of the highest PW sulphate (Fig. 3a).

We can see from Fig. 3d that from the upper part of the BDP-93 core to the $31 \mathrm{~m}$ depth, the percentage of alkali metals gradually increases among the cations; simultaneously, the relative chloride concentration increases among the anions. In the lower part of the core at the $55 \mathrm{~m}$ depth, there is a substantial decrease in both PW chloride and alkali metals while the sulphate significantly increases along with some increase in calcium ions. At the bottom of the core $(83 \mathrm{~m})$, there are nearly equal relative concentrations of $\mathrm{Ca}$ and the sum of $\mathrm{Na}+\mathrm{K}$ and approximately equal relative concentrations of PW chloride and sulphate. Such changes in PW chemistry suggest the local influence of mineralised solutions rich in sodium chloride near $31 \mathrm{~m}$ depth and calcium sulphate near $55 \mathrm{~m}$ depth. Thin sand-silt sedimentary layers, which according to (Kashik and Mazilov, 1997) occur at ap- proximately the same (31 and $55 \mathrm{~m}$ ) depths, could contribute to the seepage of these mineralised waters.

This hypothesis might be confirmed by isotopic data. On the $\delta^{2} \mathrm{H}-\delta^{18} \mathrm{O}$ diagram a major field of BDP-93 PW isotopic composition is located between the local meteoric water line and line of thermal waters from southeastern Siberia (Fig. 4). In the first time for the Baikal region, the heaviest ${ }^{18} \mathrm{O}$ isotopes with the values of -8.6 and $-7.6 \%$ SMOW (Table 5) were found in BDP-93 pore waters. Points corresponding to the heaviest isotopes are distributed along the line of thermal waters of southeastern Siberia. Thus, the composition of pore water in the BDP-93 core is a result of the interaction of meteoric waters and ambient rocks with very probable influence of modern hydrotherms (Granina et al., 1995).

2 group

In Northern Lake Baikal, besides the anomalies found along the western border (Mizandrontsev, 1975), pore waters ex- 
Table 4. Composition of pore water of anomalous composition in the sediments of Southern Lake Baikal and water of the holes drilled in the Selenga River delta

\begin{tabular}{|c|c|c|c|c|c|}
\hline \multicolumn{3}{|c|}{ Sediments of Southern Lake Baikal } & \multicolumn{3}{|c|}{$\begin{array}{l}\text { Drill holes in the Selenga River delta } \\
\text { (Lomonosov, 1974) }\end{array}$} \\
\hline $\begin{array}{l}\text { Station } \\
\text { and } \\
\text { horizon, } \\
\mathrm{cm}\end{array}$ & $\begin{array}{l}\text { Sum of } \\
\text { ions, } \\
\mathrm{mg} / \mathrm{L}\end{array}$ & $\begin{array}{l}\text { Composition of } \\
\text { pore water, } \\
\% \text { eqv. }\end{array}$ & $\begin{array}{l}\text { Drill hole } \\
\text { and horizon, } \\
\mathrm{cm}\end{array}$ & $\begin{array}{l}\text { Sum of } \\
\text { ions, } \\
\mathrm{mg} / \mathrm{L} \\
\left(\mathrm{t}^{\circ} \mathrm{C}\right)\end{array}$ & $\begin{array}{l}\text { Composition of } \\
\text { the water of holes, } \\
\% \text { eqv. }\end{array}$ \\
\hline \multirow{2}{*}{$\begin{array}{l}\text { BDP-93; } \\
142\end{array}$} & \multirow[t]{2}{*}{101} & $\mathrm{HCO}_{3} 85 \mathrm{Cl}_{5} \mathrm{SO}_{4} 10$ & \multirow{2}{*}{$\begin{array}{c}\text { Istokskaya N 4, } \\
\text { 2391-2422 }\end{array}$} & \multirow{2}{*}{$\begin{array}{c}363 \\
\left(55^{\circ}\right)\end{array}$} & $\mathrm{HCO}_{3} 85 \mathrm{Cl} 6 \mathrm{CO}_{3} 9$ \\
\hline & & $\mathrm{Ca} 54 \mathrm{Mg} 19\left(\mathrm{Na}^{+} \mathrm{K}\right) 27$ & & & Mg 2 Na 97 \\
\hline \multirow{2}{*}{$\begin{array}{l}\text { BDP-93; } \\
3120\end{array}$} & \multirow[t]{2}{*}{283} & $\mathrm{HCO}_{3} 76 \mathrm{Cl} 21 \mathrm{SO}_{4} 3$ & \multirow{2}{*}{$\begin{array}{l}\text { Istokskaya N 5, } \\
\text { 2859-2906 }\end{array}$} & \multirow{2}{*}{$\begin{array}{c}465 \\
\left(100^{\circ}\right)\end{array}$} & $\mathrm{HCO}_{3} 71 \mathrm{Cl} 21 \mathrm{SO}_{4} 8$ \\
\hline & & $\mathrm{Ca} 26 \mathrm{Mg} 8\left(\mathrm{Na}^{+} \mathrm{K}\right) 66$ & & & $\mathrm{Ca} 3 \mathrm{Na} 94$ \\
\hline \multirow{2}{*}{$\begin{array}{l}\text { BDP-93; } \\
5539\end{array}$} & \multirow[t]{2}{*}{639} & $\mathrm{HCO}_{3} 76 \mathrm{SO}_{4} 17 \mathrm{Cl} 7$ & \multirow{2}{*}{$\begin{array}{c}\text { Tvorogovskaya, } \\
1748-1753\end{array}$} & \multirow{2}{*}{$\begin{array}{c}134 \\
\left(36^{\circ}\right)\end{array}$} & $\mathrm{HCO}_{3} 53 \mathrm{SO}_{4} 28 \mathrm{Cl} 19$ \\
\hline & & $\mathrm{Ca} 44 \mathrm{Mg} 14\left(\mathrm{Na}^{+} \mathrm{K}\right) 42$ & & & $\mathrm{Ca} 54 \mathrm{Mg} 19 \mathrm{Na} 26$ \\
\hline \multirow{2}{*}{$\begin{array}{l}\text { St. } 337 ; \\
339\end{array}$} & \multirow[t]{2}{*}{449} & $\mathrm{HCO}_{3} 61 \mathrm{Cl} 33 \mathrm{SO}_{4} 6$ & \multirow{2}{*}{$\begin{array}{c}\text { Istokskaya N 1, } \\
2780-2783\end{array}$} & \multirow{2}{*}{$\begin{array}{c}526 \\
\left(86^{\circ}\right)\end{array}$} & $\mathrm{HCO}_{3} 67 \mathrm{Cl} 33$ \\
\hline & & $\mathrm{Ca} 35 \mathrm{Mg} 17\left(\mathrm{Na}^{+} \mathrm{K}\right) 48$ & & & $\mathrm{Ca} 8 \mathrm{Mg} 19 \mathrm{Na} 73$ \\
\hline \multirow{2}{*}{$\begin{array}{l}\text { St. } 316 ; \\
169\end{array}$} & \multirow[t]{2}{*}{540} & $\mathrm{HCO}_{3} 46 \mathrm{Cl} 47 \mathrm{SO}_{4} 7$ & \multirow[t]{2}{*}{ The same } & \multirow{2}{*}{$\begin{array}{c}526 \\
\left(86^{\circ}\right)\end{array}$} & $\mathrm{HCO}_{3} 67 \mathrm{Cl} 33$ \\
\hline & & $\mathrm{Ca} 28 \mathrm{Mg} 18\left(\mathrm{Na}^{+} \mathrm{K}\right) 54$ & & & $\mathrm{Ca} 8 \mathrm{Mg} 19 \mathrm{Na} 73$ \\
\hline
\end{tabular}

Table 5. Isotopic composition of meteoric and surface waters in Baikal region and Baikal pore water, \%o relatively SMOW

\begin{tabular}{|c|c|c|}
\hline & $\delta^{18} \mathrm{O}$ & $\delta^{2} \mathrm{H}$ \\
\hline Baikal pore water & from -7.6 to -21.6 & from -102 to -156.5 \\
\hline $\begin{array}{l}\text { Meteoric and surface waters of Eastern } \\
\text { Siberia (Lomonosov, 1974) }\end{array}$ & from -10.9 to -19.3 & from -90 to -210 \\
\hline $\begin{array}{l}\text { Atmospheric precipitation above Irkutsk } \\
\text { (Seal and Shanks, 1998) }\end{array}$ & from -9 to -25 & from -65 to -213 \\
\hline $\begin{array}{l}\text { Atmospheric precipitation above Baikal } \\
\text { and waters of Baikal tributaries } \\
\text { (Seal and Shanks, 1998) }\end{array}$ & from -11.4 to -21.7 & from -95.8 to -160.3 \\
\hline
\end{tabular}

hibit an unusual composition near the eastern shore. There is a centre of underwater discharge in Frolikha Bay (Fig. 1) that is believed to be a region of hydrothermal venting located on crossing tectonic faults. Heat flux from the bottom is the highest for the whole lake and the waters just above the bottom sites with high heat fluxes are characterized by increased temperature and electrical conductivity (Golubev, 1993). Obviously, thermal water discharge should affect the geochemistry of sediments and pore waters. Actually, both our (Fig. 5, Tables 1-3) and published (Callender and Granina, 1992; Shanks and Callender, 1992; Granina et al., 1994; Pavlov, 1994; Granina et al., 1999) data show that PW anomalies appear just at the very top of the sediments.

Short cores taken at stations $4,6,8,10$ in the region of sub-aquatic hydrothermal discharge were studied in comparison with control cores sampled at neighbouring stations 3 and 11 (Fig. 1). Sum of ions in PW at control sites averages $110 \mathrm{mg} / \mathrm{L}$. In the vent region, the average is $658 \mathrm{mg} / \mathrm{L}$, a value close to the maximum TDS in thermal springs of Pribaikal'e, which is, according to (Lomonosov, 1974), $700 \mathrm{mg} / \mathrm{L}$. Gradient in pore water TDS does not exceed $1.3 \mathrm{mg} \mathrm{L}^{-1} \mathrm{~cm}^{-1}$ at the control sites whereas it varies between 13 and $55 \mathrm{mg} \mathrm{L}^{-1} \mathrm{~cm}^{-1}$ in the vent area, thus testifying to the influence of mineralised waters. Increased TDS at st. 4, 6, 8 are mainly due to bicarbonate and $\mathrm{Na-ion}$ and, to some extent, chloride. This is confirmed by high values of corresponding correlation coefficients, which are from 0.95 to 1 . However, the role of chloride is not significant. Weak enrichment in PW chloride occurs just in the lowest horizons of the cores, reaching only $5 \mathrm{mg} / \mathrm{L}$ at st. 4,8 and $30 \mathrm{mg} / \mathrm{L}$ at st. 6. Coupled correlations are found for $\mathrm{Na}-\mathrm{HCO}_{3}$ and $\mathrm{Na}-$ $\mathrm{Cl}$ ions (Table 3), whereas there is not any correlation for these ions at the control sites. Concentrations of PW bicarbonate and $\mathrm{Na}$ (in some cases $\mathrm{Ca}$ ) are much higher compared to all other PW ions (Fig. 5). One may conclude about the concentrations from the data presented in Tables 1-3.

There is quite different PW chemistry at st. 10. The Na$\mathrm{Cl}$ relation is stronger at this site (Table 3). However, the 

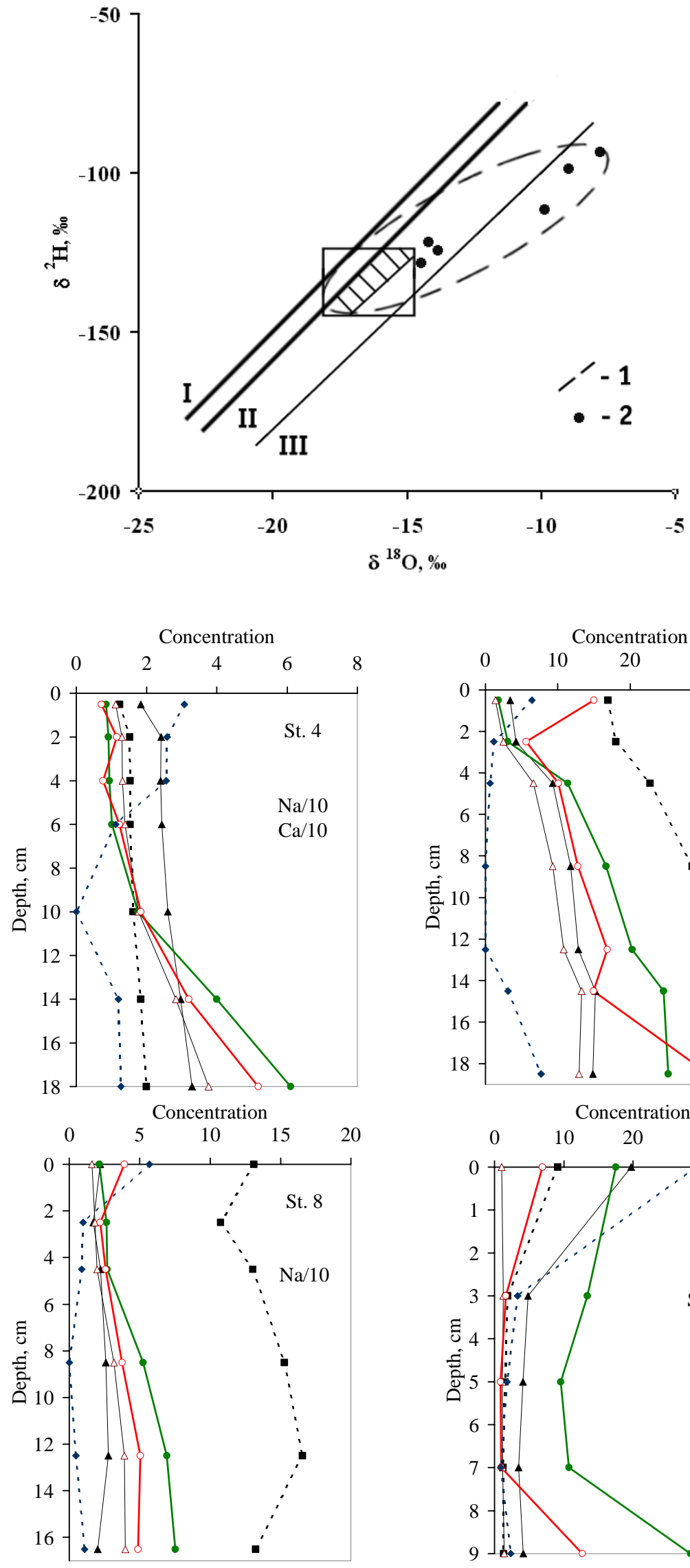

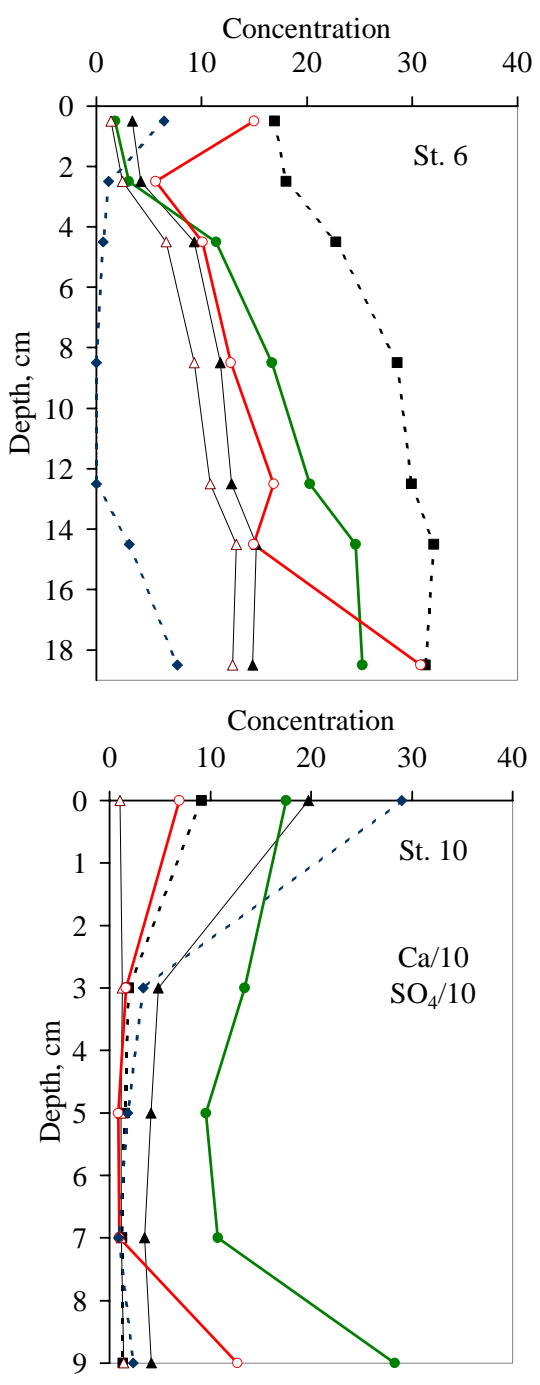

Fig. 4. Stable isotopes in pore water of BDP-93 core in comparison with generalized data on isotopic composition of different types of water. Major field of isotopic composition of pore water in BDP-93 core is shaded.

I - global meteoric water line; II - local meteoric water line (Baikal region); III - thermal waters of the south of Eastern Siberia; I-III - from (Pinneker, 1977).

1 - pore water in BDP-93 core; 2 maximal $\delta^{18} \mathrm{O}$ values in BDP-93 pore water.
Fig. 5. Profiles of major pore water ions in the region of hydrothermal vent in Frolikha Bay (st. 4, 6, 8, 10). Designations are the same as for Fig. 2. 
highest chloride concentration is only $13 \mathrm{mg} / \mathrm{L}$. The bicarbonate concentration is also low $(67-86 \mathrm{mg} / \mathrm{L})$, being close to the "background" value; concentration of PW sulphate is almost 90 times higher compared to that at the control sites (Table 1). It is balanced by a corresponding increase (6-10 times) in the concentration of all cations. There is a direct relationship between PW sulphate and cations (Table 3). Due to intensive sulphate reduction, no pore water enrichment in sulphate is found at any other station (Table 2).

Thus, the influence of mineralised sodium bicarbonate waters, which are responsible for high TDS, is observed at most stations that were studied in the hydrothermal vent area. In a sandy layer located at the sediment-water interface at st. 10, the influence of potassium-magnesium-calcium sulphate waters is noted (Table 3, Fig. 5). In a surface sedimentary layer at st. 4, there is an elevated concentration of bromide $(5.9 \mathrm{mg} / \mathrm{L})$, an element not typical of Lake Baikal pore water, except as noted earlier in the BDP-93 core.

The lightest stable isotopes ${ }^{18} \mathrm{O}(-21 \%)$ and ${ }^{2} \mathrm{H}(-155 \%)$ in Lake Baikal pore water are found at st. 6. Their composition coincides with that of the waters from thermal springs of Northern Pribaikal'e as presented in (Seal and Shanks, 1998). Not only pore waters, but also waters from the neighbouring terrestrial thermal spring Frolikha (Fig. 1) were analysed at the same time: concentrations of sulphate $(101 \mathrm{mg} / \mathrm{L})$ and $\mathrm{Na}$ ion $(73.6 \mathrm{mg} / \mathrm{L})$ exceeded that in Lake Baikal waters by 21 and 18 times respectively. It follows from the data presented in Tables 1 and 2 that PW in the vent area is also enriched in $\mathrm{Na}$ ion (and in sulphate at st. 10). These data suggest the existence of the same source of terrestrial and sub-aquatic thermal water discharge.

In accordance with (Granina et al., 1999), pore waters in the vent area are enriched in some minor elements: $\mathrm{Sr}, \mathrm{Sc}$, $\mathrm{Zn}, \mathrm{Mo}, \mathrm{Cr}, \mathrm{W}, \mathrm{Be}, \mathrm{As}, \mathrm{Nb}, \mathrm{Ba}$. Another peculiarity of this PW chemistry is the extensive heterogeneity: in spite of very small difference in the location of sites studied, PW chemistry differs significantly from station to station. This may reflect the extremely local influence of thermal waters. Published data also indicate that there are point sources of subaquatic water discharge in Frolikha Bay (Kipfer et al., 1996).

Thus, high concentrations of PW sulphate, chloride, and $\mathrm{Na}$ are found at some sites in Southern Lake Baikal; of PW bicarbonate and $\mathrm{Na}$ and, in some cases, of sulphate in the Frolikha Bay vent area in Northern Lake Baikal (Table 1). In the area of groundwater hydrothermal discharge, the PW anomalies are the clearest, the most mosaic, and diverse.

\section{Discussion}

Data presented in Table 4 indicate that pore waters in Lake Baikal are meteoric in origin. At the same time, in different regions of the lake and at different depths within the sediment column, pore waters are substantially enriched in some components that are not major constituents of the ambient sediments, and such enrichments are not the result of simple water- sediment interaction. For example, the region of
Northern Baikal (including Frolikha Bay area) is totally composed in granitoids and there are not rocks, like evaporates, which could serve as sources of anomaly-forming components. In this connection, an influence of remote sources of anomaly-forming components needs to be assumed. A probability of such influence and its possible mechanism follow from the peculiarities of the total fault structure in Baikal rift.

Data presented above as well as some published materials, listed below, argue that there is a genetic relationship between centres of terrestrial and sub-aquatic hydrothermal discharge in Northern Baikal. Like this, the mean content of TDS in PW in the Frolikha vent area coincides with the highest one of thermal springs of Pribaikal'e. Both these pore waters and waters of terrestrial thermal spring Frolikha are enriched in $\mathrm{Na}$ ions, sulphates, as well as in some minor elements - Mo, Cr, W, Sr (Granina et al., 1999). Such elements as $\mathrm{Sr}, \mathrm{Br}, \mathrm{W}, \mathrm{Zn}$ are common minor elements in modern terrestrial hydrotherms in the Baikal Rift Zone (BRZ) (Lomonosov, 1974) and exactly these same elements are found, according to our data (Granina et al., 1999), in Frolikha Bay pore waters. In this area, composition of PW stable isotopes at the deepest horizons of short cores is similar to that in the waters of terrestrial thermal spring Frolikha (Shanks and Callender, 1992).

At st. 10 concentration of the helium dissolved in nearbottom water exceeds 8 background units (Pavlov, 1994). This element may enter through the zones of increased permeability, since it is known that there is helium in thermal spring waters in Pribaikal'e (Lomonosov, 1974). Results of $\mathrm{He}$ isotopes investigation testify that part of the $\mathrm{He}$ in the hydrothermal water originates from the earth crust; they confirm an existence of one source of terrestrial and sub-aquatic discharge in Frolikha Bay (Kipfer et al., 1996). Apparently, this is not the only example of such a genetic relationship. It is possible to trace a relationship between sodium sulphate waters that are substantially enriched in chloride and fluoride of the terrestrial spring Kotelnikovskii on the western shore of Lake Baikal (Lomonosov, 1974) and PW from adjacent bottom sediments (st. 40, 41 on Fig. 1) that are enriched according to (Mizandrontsev, 1975) in chloride, sulphate, and alkali metal ions. Such a genetic relationship between terrestrial and sub-aquatic water discharge is obvious because they are connected by large fault systems.

Meteoric waters flow into the open zones of major faults located along the western border of the Baikal depression. Most of the faults exit to the surface above the lake level up to $500 \mathrm{~m}$ elevation; fault zones are of listric type and plateaus with depth. Penetrating into the deep zone, the waters move laterally. They gather the heat, are warmed and enriched in the components of ambient rocks. Along the minor faults of eastern borderland, hot waters rise to the surface and form numerous mineral thermal springs that are located presumably in the coastal zone, close to the Baikal level (Fig. 1). Part of them, as it is exemplified by the data on Frolikha Bay PW chemistry presented in this paper, may discharge on the lake bottom. The most recent data (Golubev, 2002) confirm that in the BRZ the heat is transported by ground 
waters being redistributed within about $5 \mathrm{~km}$ thick sedimentary layer due to forced convection caused by heights-depths difference.

Extending our understanding of the modern hydrotherms formation in BRZ (Lomonosov, 1974) to Lake Baikal pore water that is genetically linked with hydrotherms, we believe that PW constituents are probably the result of leaching of ambient rocks. However, a fraction of PW sulphate, halogens, and minor elements may have multiple geneses, including the input of fluids from deep zones of the earth's crust and mantle. Slowly, during a long period of time, these components (probably as ions and molecules) are seeping through the zones of increased permeability in the areas of tectonic instability.

Entering the sedimentary sequence, the fluids enriched in numerous components are able to penetrate through sandy layers. However, a question arises as to how they could migrate through clayey sediments (aquiclude). The effect of "vagabonding sieves" (Vartanyan and Goldberg, 1996) may serve as possible explanation. It works as follows: if some part of the water-pressure system is stretching, the micro-pore space of the clayey sequences may open periodically. Rising discharge of high- pressure (mineralised, heated) ground waters occurs at this time. When deformation changes from stretching to compression, the input of rising fluids stops, and the "vagabonding sieve" is translated into another part of the water-pressure system (Vartanyan and Goldberg, 1996). In the seismically-active Baikal rift zone, characterized by wide-spread strains of stretching and compression, a similar mechanism may provide the transport of hydrothermal water fluids through friable deposits, including clayey ones.

It was shown above (Tables 1 to 3 ) that PW anomalies are expressed differently in the southern and northern basins. Let's consider how these differences correspond to the scheme of deep, vertical hydrogeochemical zonality within the BRZ. In accordance with the scheme (Lomonosov, 1974), bicarbonate and sodium bicarbonatesulphate hydrotherms are presumably formed in the upper part of the rift (up to $3 \mathrm{~km}$ depth) where temperatures up to $100^{\circ} \mathrm{C}$ dominate. As we showed above, sub-aquatic discharge of this nature takes place in Frolikha Bay.

At depths of 3 to $6 \mathrm{~km}$, where temperatures exceed $100^{\circ} \mathrm{C}$, there is a hydrogeochemical zone characterised by the formation of sulphate and sodium chloride-sulphate hydrotherms (Lomonosov, 1974). However, in contrast to this scheme, at a depth of only 2 to $3 \mathrm{~km}$, non-zonal ground waters were discovered by oil-drilling holes in the Selenga River delta (Fig. 1). There was sodium bicarbonate-chloride water at a depth of about $3 \mathrm{~km}$ in Istokskaya $\mathrm{N} 1$ hole and high concentration of sulphate at a depth of about $2 \mathrm{~km}$ in the Tvorogovskaya hole (Lomonosov, 1974). The water temperature ranged between $36^{\circ}$ and $100^{\circ} \mathrm{C}$ and the percentage of sulphate and chloride was up to 28 and $33 \%$ eqv., and that of $\mathrm{Na}$ ion was 73 to $97 \%$ eqv. (Table 4). These ground waters of specific composition, occurring within sands of Miocene age, are relics of ancient salt lakes (Dzyuba and Kulagina,
2000). They are distributed in the region, adjacent to which we found pore waters characterized by anomalously high content of sulphate, chloride, and Na ion (Fig. 1). It is logical to suppose that these ground waters may serve as a source of ions that enrich the pore waters of Southern Lake Baikal. Data presented in Table 4 show that the sum of ions is of the same order of magnitude $(100-600 \mathrm{mg} / \mathrm{L})$ in the most enriched pore waters as in the waters of the drill holes. Moreover, one may find "an analogue" of PW among the waters of the drill holes that are characterised by a rather similar anion composition. Differences mainly concern the content of sulphate and are determined by the intensity of sulphate reduction. The composition of cations differs more; as a rule, there is more sodium and/or magnesium in the water of the drill holes compared to the cation composition in PW. This is a result of the processes of cation exchange and leaching. A similar tendency for cations to change their ratio with depth was observed in PW of the 100-m BDP-93 core (see above). Thus, at 2 to $3 \mathrm{~km}$ depth it should be more pronounced.

Just near the Selenga River delta region, the crystals of gas hydrates have been recently found within the upper $25 \mathrm{~cm}$ of lake sediments that are characterised by anomalies in PW composition (Fig. 1) (Klerkx et al., 2000; Granina et al., 2000). The porewater in gas-hydrate-bearing sediments is characterized by a high concentration of sulphate (up to $15 \mathrm{mg} / \mathrm{L}$ ) and chloride (more than $100 \mathrm{mg} / \mathrm{L}$ ) (Granina et al., 2000). It is likely that the same relics of ancient salt lakes could serve as a source of PW ions for these sediments. These constituents are able to penetrate friable deposits through the zones of increased permeability, since this part of the lake bottom is bordered, in accordance with (Klerkx et al., 2000), by crossing faults.

\section{Conclusion}

Porewaters of specific composition are found at different horizons within the sediment column at several locations in Lake Baikal. They are characterised by anomalously high concentrations of some of the major ions and, in some cases, by the presence of rare minor elements.

PW anomalies have specific features in each of the basins. It is shown that there is a generic relationship between subaquatic and terrestrial centres of thermal-water discharge in Northern Lake Baikal. Anomaly-forming constituents enter the pore water probably as a result of leaching of ambient sediments. In addition, a fraction of the sulphate, halogens, and minor elements may have multiple geneses that include the input of fluids from deep zones of the earth's crust and mantle. Data on Frolikha Bay PW chemistry presented in this paper exemplify that besides terrestrial there is also a sub-aquatic hydrothermal water discharge in Lake Baikal.

In Southern Lake Baikal, non-zonal ground waters of specific composition are found in the Selenga River delta, which represent relics of ancient salt lakes and may serve as a source of the anomaly-forming components. Their influence may be realized through the zones of increased permeabil- 
ity that are widely spread throughout this area. The effect of "vagabonding sieves" could contribute to penetration of water fluids through friable deposits, including clayey ones. This effect may be of great importance in the seismicallyactive zone of the Baikal rift.

Acknowledgements. The authors thank the members of the crew of $\mathrm{s} / \mathrm{v}$ "Vereschagin" for their help during fieldwork. Special thanks to Prof. M. A. Grachev, the director of Limnological institute, for his support of this study, and to Prof. J. Klerkx for organizing the expedition to Frolikha Bay. We are appreciative to Professors I. S. Lomonosov and I. B. Mizandrontsev for the draft discussion and valuable comments. The work is partly supported by RFBS grant N 99-05-65680.

\section{References}

Callender, E. and Granina, L.: Transition metals geochemistry of sedimentary pore fluids associated with hydrothermal activity in Lake Baikal, Russia, in: Kharaka, Y. K. and Maest, A. S. (Eds.): Water-Rock interaction (Proceedings of the 7th International Symposium), Rotterdam, 621-626, 1992.

Dzyuba, A. A. and Kulagina, N. V.: Relict salt lakes of the Selenga River delta, in: The third Vereschagin Baikal conference, Abstracts of reports, Irkutsk, 77, 2000.

Falkner, K. K., Measures, C. I., Herbelin, S. E., and Edmond, J. M.: The major and minor element geochemistry of Lake Baikal, Limnol. Oceanograp., 36, 413-423, 1991.

Golubev, V. A.: Centres of sub-aquatic hydrothermal discharges and heat balance of Northern Baikal, Doklady Akademii Nauk, in Russian, 328, N3, 315-318, 1993.

Granina, L. Z., Klerkx, J., and Callender, E. et al.: Geochemistry of pore water in the region of hydrothermal vent, Frolikha Bay, Northern Baikal, in: Baikal - natural laboratory for global change, Abstracts, V.6. Irkutsk, 12-13, 1994.

Granina, L. Z., Callender, E., Golobokova, L. P., and the team of the authors: Results of drilling of first hole in Lake Baikal in the region of Buguldeika dam, Geologiya i Geofizika, in Russian, 36, N2, 3-32, 1995.

Granina, L. Z., Callender, E., Klerkx, J. et al.: Peculiarities of the bottom sediments biogeochemistry in the region of hydrothermal discharge in Lake Baikal, in: Geochemistry of Landscapes, Palaeoecology of Man and Ethnogeny, Abstracts of Intern. Symposium - September 6-11, Ulan-Ude, 299-301, 1999.
Granina, L. Z., Golobokova, L., Zemskaya, T., Khlystov, O., and Granin, N.: Geochemical characteristic of the surface sediments in the region of gas hydrates occurrence in Southern Lake Baikal, in: VI International Conference on Gas in Marine Sediments, St. Petersburg - September 5-9, 37-39, 2000.

Golubev, V. A.: Conductive and convective heat efflux in the Baikal Rift Zone, Author's abstract of dissertation, Irkutsk, 77, in Russian, 2002.

Jahnke, R. A.: A simple, reliable, and inexpensive pore-water sampler, Limnol. Oceanogr., 33, 483-487, 1988.

Kashik, S. A. and Mazilov, V. N.: Lithology of quaternary sediments in the section of deep hole in aquatorium of Lake Baikal, Lithologiya i Poleznye Iskopaemye, in Russian, N 5, 484-491, 1997.

Kipfer, R., Aeschbach-Hertig, W., and Hofer, M. et al.: Bottomwater formation due to hydrothermal activity in Frolikha Bay, Lake Baikal, eastern Siberia, Geochim. Cosmochim. Acta, 60, 961971, 1996.

Klerkx, J., Hus, R., and De Batist, M. et al.: The structural control of the methane venting area at the southern basin of Lake Baikal, Siberia, in: VI International Conference on Gas in Marine Sediments, St. Petersburg - September 5-9, 56, 2000.

Lomonosov, I. S.: Geochemistry and formation of modern hydroterms of Baikal rift zone, Novosibirsk, Nauka, in Russian, 165 p., 1974

Mizandrontsev, I. B.: To the geochemistry of pore waters, in: Galazii, G. I. and Parmuzin, Yu. P. (Eds.): Dynamics of Baikal depression, Novosibirsk, Nauka, in Russian, 203-230, 1975.

Pavlov, S. Kh.: New hydrogeochemical data on fluids discharge into bottom of Lake Baikal, in: Abstracts of IV Intern. Symposium on problems of applied geochemistry, V.2, Irkutsk, in Russian, 130-131, 1994.

Pinneker, E. V.: Problems of regional hydrogeology. Regularities of distribution and formation of ground waters, M., Nauka, in Russian, 196 p., 1977.

Seal, R. R., II, and Shanks, W. C., III: Oxygen and hydrogen isotope systematics of Lake Baikal, Siberia: Implications for paleoclimate studies, Limnol. Oceanogr., 43, 1251-1261, 1998.

Shanks, W. C., III, and Callender, E.: Thermal springs in Lake Baikal, Geology, 20, 495-497, 1992.

Vartanyan, G. S. and Goldberg, V. M.: Influence of variability in clays permeability and strain rocks state on the conditions of closing of water-bearing systems, Otechestvenaya Geologiya, in Russian, 8, 43-47, 1996. 